\title{
151. On the Genus Swedenborgia Nathorst and its Occurrence in the Nariwa Bed, Okayama Pref., Japan.
}

\author{
By Saburo ÔISHI and Kazuo Yamasita. \\ Department of Geology and Mineralogy, Hokkaido Imperial University, Sapporo. \\ (Comm. by H. YABE, M.I.A., Dec. 12, 1935.)
}

The genus Swedenborgia was instituted by Nathorst ${ }^{1)}$ in 1876 for some lax oval strobili from Palsjö bearing small cone-scales with a long stalk and arranged spirally around a slender axis. The monotypic species S. cryptomerioides Nath. ${ }^{2)}$ was later described also by Saporta ${ }^{31}$ and Antevs ${ }^{4}$ from Palsjö and Muehlstein respectively. Nathorst compared the strobili with those of Cryptomeria and mentioned the presence of a single seed as an essential distinguishing character of this genus, though Harris, ${ }^{5)}$ who described, besides S. cryptomerioides, two more species, $S$. major and $S$. minor, from the basal Liassic (or Rhaeto-Liassic) bed of eastern Greenland, mentioned that each conescale bears five seeds. Harris ${ }^{6)}$ showed a restoration of a cone-scale of $S$. cryptomerioides seen from above and below, and stated that the lower surface is concave with a small outgrowth from the stalk projecting into the base of the concavity, while the upper surface, which is convex, bears five small upgrowths (seed-bearing? by Harris) at the base of each of the five lobes into which the distal portion of a scale is divided. Harris' supposition that Swedenborgia is five-seeded seems to be natural judging from his restoration. The foliage is not known. However, Harris states, "there is evidence of association for suggesting that it may belong to certain narrow-leaved species of Podozamites of the $P$. schenki-P. agardhianus group."

The Japanese specimens now at hand are not sufficient to add any biological evidence as to the nature of these strobili, but the occurrence of this genus in far eastern Asia is somewhat notable as it has not yet been recorded outside Europe; its occurrence is very rare and it is a plant very interesting from the palaeobotanical point of view. The Japanese specimens comprise two distinct forms, namely, S. cryptomerioides Nath. and S. major Harris. They occurred at Hinabata (Loc. No. 44) in the Nariwa district in association with the following species ${ }^{7)}$ :

1) A. G. Nathorst: Bidrag till Sveriges Fossila Flora. I. Kgl. Svensk. Vet.-Akad. Handl., XIV, No. 3, 1876, p. 65.

2) A. G. Nathorst: Ibid., p. 66, Pl. XVI, figs. 6-12. Beitraege zur fossilen Flora Schwedens, 1878 , p. 30 , Pl. XVI, figs. 6-12.

3) M. de Saporta: Plantes Jurassiques, T. III, 1884, p. 528, Pl. CXCVIII, figs. 1-4.

4) E. Antevs: Die liassische Flora des Hoersandsteins. Kgl. Svensk. Vet.-Akad. Handl., Bd. LIX, No. 8, p. 48, Pl. V, figs. 31-37.

5) T. M. Harris: The Fossil Flora of Scoresby Sound, East Greenland. Pt. 4. Med. om Grфnland, Bd. CXII, No. 1, 1935, p. 107.

6) T. M. Harris: Ibid., Pl. XIX, figs. 5, 6.

7) Species from Loc. No. 44 in the Nariwa district have been described in Ôishi's The Rhaetic Plants from the Nariwa District. Journ. Fac. Sci., Hokkaidô Imp. Univ., Ser. IV, Vol. I, Nos. 3-4, 1932. 
Marattiopsis Muensteri (Goepp.), Todites Williamsoni (Brongn.), Cladophlebis haiburnensis (L. and H.), C. gigantea Ôishi, C. bitchuensis Ôishi, C. nebbensis (Brongn.), C. Raciborskii Zeill., C. Raciborskii Zeill. forma integra Ôishi and Takahasi, C. pseudodelicatula Ôishi, Clathropteris obovata Ôishi, Sphenopteris gracilis Ôishi, Pterophyllum Jaegeri Brongn., Nilssonia orientalis (Heer), Ginkgoites sibirica (Heer), Baiera paucipartita Nath., Pityophyllum (Pityocladus) longifolium (Nath.), Podozamites lanceolatus (L. and H.).

The plant bed belongs to the Nariwa Series which approximately corresponds in age to the Rhaetic, though its upper part may be basal Liassic. The description follows.

1

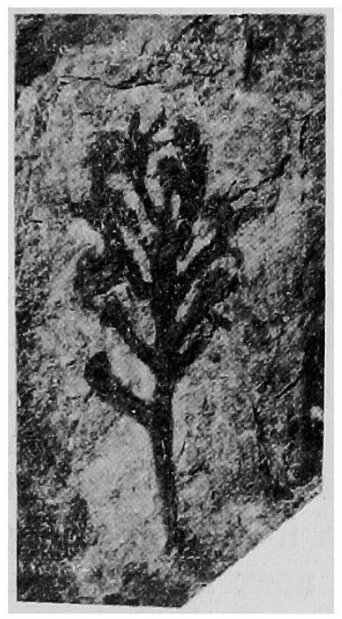

3

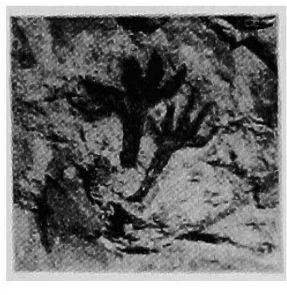

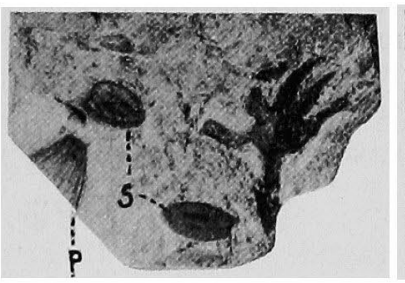

4

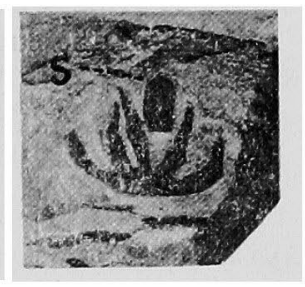

Figs. 1-3. Swedenborgia cryptomerioides Nath. $\times 1$.

Fig. 4. S. major Harris. $\times 1$.

(S, seeds ; P, Podozamites leaf).

\section{Swedenborgia cryptomerioides Nathorst}

Figs. 1-3.

Fig. 1 shows a lax strobili $3.5 \mathrm{~cm}$ long with small cone-scales $1.2 \mathrm{~cm}$ long, bearing a short stalk arranged spirally around a slender axis $1.5 \mathrm{~mm}$ thick. The cone-scale is expanded distally and divided palmately into five almost equal rigid lobes $3 \mathrm{~mm}$ long and apically sharply pointed. There is no trace of seeds. The preservation of this specimen is somewhat unsatisfactory.

Fig. 2 shows two cone-scales at least $1.2 \mathrm{~cm}$ long. They may have arisen from a common axis, but there is no indication of it. The upgrowths as were observed by Harris are not seen. The cone-scale in fig. 3 is specially interesting as it occurred in close association with seeds which show close agreement in size and form with those figured from Palsjö by Nathorst" ${ }^{1)}$ who supposed that they belonged to Swedenborgia cryptomerioides. Similar seeds were also found in association with S. cryptomerioides in Greenland. ${ }^{2)}$ Therefore, it should be strongly emphasized that the seeds are of Swedenborgia. At the same time it is nearly certain that the Japanese specimens now at hand are specifically identical with those from Sweden and Greenland called under the name S. cryptomerioides. The surface of the expanded part of the

1) A. G. Nathorst: Op. cit., 1876 and 1878.

2) T. M. Harris: Op. cit., 1935. 
cone-scale is convex. Therefore, it is presumable that this is the upper surface. The upgrowth can not be seen. The seed is oval and flat, $6 \mathrm{~mm}$ and $2 \mathrm{~mm}$ broad, the one end concave, while the other bluntly pointed, with delicate marginal wing $0.5 \mathrm{~mm}$ wide. Harris states, "the wing ceases just below the apex leaving a notch which is occupied by the projecting micropyle," but such detail can not be made out in the present specimens.

The senior author1) formerly described a fossil from Suimyô in the Nariwa district which he thought to be a leaf-sheath of an Equisetalean plant, under the name Phyllotheca sp. Though it is fragmentary, the specimen resembles the distal portion of cone-scale of Swedenborgia; it is probable that this Phyllotheca sp. represents an imperfect cone-scale of this interesting genus now under discussion. The general shape and size of the supposed leaf-sheath show that it is a type close to S. cryptomerioides.

\section{Swedenborgia major Harris}

Fig. 4.

Fig. 4 shows a cone-scale of Swedenborgia lacking the stalk. The principal part of the cone-scale is very narrow in this specimen, but the lobes five in number are $7-8 \mathrm{~mm}$ long and curved. A seed is seen in an intimate relation to the lobes. It is similar in form to that in fig. 3, but differs slightly from it in being shorter $(4 \mathrm{~mm}$ long and $2 \mathrm{~mm}$ broad). The marginal wing is $0.5 \mathrm{~mm}$ wide as in the preceding specimen. The base is evidently concave and the apex seems to be rounded. More details are not available. As far as the present specimen is concerned the seed in this differs little from that associated with $S$. cryptomerioides. It is also the same in the Greenland specimens, as mentioned by Harris. ${ }^{2}$

1) S. Ôishi: The Rhaetic Plants from the Nariwa District, Prov. Bitchû (Okayama Prefecture), Japan. Journ. Fac. Sci., Hokkaidô Imp. Univ., Ser. IV, Vol. I, Nos. 3-4, 1932, p. 267, Pl. II, fig. 10 .

2) T. M. Harris: Op. cit., 1935, p. 109. 